\title{
Música y propaganda en dos filmes animados producidos por Disney durante la Segunda Guerra Mundial
}

\author{
Music and Propaganda in two animated films produced by \\ Disney during the Second World War.
}

\author{
por \\ Juan Carlos Poveda Viera \\ Instituto de Música, Universidad Alberto Hurtado, Chile \\ jpoveda@uahurtado.cl
}

Durante la primera mitad de la década de 1940 y en el contexto de la Segunda Guerra Mundial, los estudios Disney produjeron, con apoyo y supervisión del gobierno estadounidense, una gran cantidad de filmes propagandísticos. Entre estos se encontraban Saludos Amigos (1942) y The Three Caballeros (1944), filmes de animación destinados a mejorar las relaciones diplomáticas con América Latina. Si bien ambas producciones han sido objeto de diversos estudios, estos han sido, por lo general, indiferentes a la dimensión de lo sonoro y lo musical, componente que resultó ser uno de los recursos más persuasivos y estratégicos desplegados por el gobierno estadounidense, por medio de la industria fílmica, para apelar a las emocionalidades de las audiencias americanas en pos de su proyecto de hegemonía. A modo de contribuir a contrarrestar lo anterior, se analiza aquí la música contenida en ambas producciones, pensando en las maneras en que esta contribuye a reforzar su lenguaje propagandístico. Asimismo, se ofrece hacia el final del escrito una breve reflexión acerca de la infancia, tanto como una destinataria más de un lenguaje propagandístico abundante en caos, sexualización y otros elementos narrativos cercanos al lenguaje representacional de Hollywood, pero lejanos a otras producciones de Disney del período y a los códigos culturales relacionados con la infancia; así como también desde la indiferencia hacia el sujeto infantil presente en la literatura académica revisada, esto a pesar de la estrecha relación de las producciones de Disney con el mundo infantil.

Palabras clave: música e infancia; cine infantil; propaganda; política del buen vecino; imperialismo cultural; Disney.

During the first half of the 1940s and in the context of World War II, Disney studios produced a large number of propaganda films with the support and supervision of the US government. Among these were Saludos Amigos (1942) and The Three Caballeros (1944), two animation films to strategically improve diplomatic relations with Latin America. Although various authors have studied both productions, they have generally been indifferent to the dimension of sound and music, a component that turned out to be one of the most persuasive and strategic resources deployed by the US government, through the film industry, to appeal to the emotionalities of American audiences in pursuit of its hegemony project. This article analyzes both productions' music to help counteract this by thinking about how it contributes to reinforcing their propaganda language. Likewise, towards the end of this article, a brief reflection on childhood is offered, both as one more recipient of a propaganda language abundant in chaos, sexualization, and other narrative elements close to Hollywood's representational language, but far from other Disney productions of the period and the cultural codes related to childhood. In addition, it reflects on the indifference towards childhood present in the academic literature reviewed, this despite the close relationship of Disney productions with the children's world.

Keywords: Music and Childhood; Propaganda; Good Neighbor Police; Cultural Imperialism; Disney. 


\section{INTRODUCCIÓN: EL UNIVERSO DE DISNEY COMO NUEVO RECURSO DE PROPAGANDA ${ }^{1}$}

El 31 de octubre de 1940, el legendario dibujante y empresario fílmico Walter "Walt" Elias Disney recibió un memorándum de su hermano Roy, cofundador y responsable de los asuntos económicos de los estudios Walt Disney². En dicho documento, Roy Disney daba cuenta de una reunión sostenida el día anterior entre él y Gunther Lessing -abogado de los estudios- con dos representantes del gobierno estadounidense: John Hay Whitney una influyente figura dentro del mercado hollywoodense- y su entonces asistente, Francis Alstock. La conversación de dicha cita se centró en la misión diplomática que estaba llevando adelante Nelson Rockefeller, por entonces un joven político republicano designado por el presidente F. D. Roosevelt para ayudar a mejorar las relaciones comerciales y culturales entre Estados Unidos y los países latinoamericanos en el marco de la llamada "Política del buen vecino"'. En esa línea, Whitney y Alstock manifestaron su interés en que los estudios Disney mantuvieran buenas relaciones con los mercados fílmicos latinoamericanos ${ }^{4}$, además de pedir incluir, en palabras de Roy Disney, "cierta atmósfera sudamericana en algunos cortometrajes, esto a modo de contribuir a la causa general por medio de cosas como el Gaucho"5.

Tanto Whitney como Alstock trabajaban en la recién inaugurada Oficina del Coordinador de Asuntos Interamericanos (en adelante OCIAA), entidad dirigida por Rockefeller, que desde sus inicios fue clave en la producción, distribución y monitoreo de propaganda durante el desarrollo de la Segunda Guerra Mundial, misión en la que Hollywood se convirtió en una de sus armas más estratégicas y eficaces.

1 Este artículo constituye una versión revisada y expandida de un subcapítulo de mi tesis "HELLO FRIENDS, CANTEMOS: La música en las representaciones de lo latinoamericano en largometrajes de ficción hollywoodenses durante el período de la Política del buen vecino”, desarrollada para obtener el grado de Doctor en Estudios Latinoamericanos.

2 Parte del documento en cuestión puede consultarse en el trabajo de Kaufman (2009:17).

3 La "Política del buen vecino" puede entenderse, en términos generales, como una iniciativa de la política exterior estadounidense que se desarrolló a partir de la proclamación de la metáfora del "buen vecino" contenida en el discurso inaugural del primer gobierno de Franklin Delano Roosevelt (4 de marzo de 1933) y cerró su ciclo con la muerte de Roosevelt, acaecida el 12 de abril de 1945, y el fin de la Segunda Guerra Mundial, desarrollado progresivamente durante ese mismo año. En claro contraste con el pasado, esta política proponía la no injerencia de Estados Unidos en los asuntos internos de los países de Latinoamérica y Caribe, favoreciendo asimismo el intercambio comercial y los tratados bilaterales con los países "vecinos". Es importante destacar que la diplomacia cultural jugó aquí un rol estratégico.

4 Según Kaufman, Roy Disney habría replicado que, hasta ese momento, los estudios Disney habían estrenado en América Latina los largometrajes animados Snow White and the Seven Dwarfs (Cottrell et al. 1937) y Pinocchio (Ferguson et al. 1940), así como varios cortometrajes, todo en versiones dobladas al castellano y al portugués, esto hasta que el costo del doblaje se hizo insostenible (2009:17).

5 “(...) some South American atmosphere in some of the short subjects in order to help the general cause along-some such thing as el Gaucho" [Las traducciones en este texto son personales]. En relación con la alusión a un "gaucho", probablemente Roy Disney se refería específicamente a uno de los primeros cortometrajes animados de Disney, The Gallopin' Gaucho (Iwerks 1928), el que desarrolla las aventuras de un gaucho (personificado por Mickey Mouse) prófugo de la justicia, parodiando, a su vez, algunos clichés ya instalados en las audiencias estadounidenses por medio de filmes como The Four Horsemen of the Apocalipe (Ingram 1921), The Gaucho (Jones 1927) o Hi, Gaucho (Atkins 1935). 
En virtud de lo anterior, no resultaba extraño que la OCIAA pensara en Walt Disney como un embajador cultural que trabajara, de manera solapada, para los intereses del gobierno.

Por aquellos años, el dibujante y empresario oriundo de Chicago ya había alcanzado la cúspide de su carrera (Watts 1997). Como una figura famosa, querida y respetada, Disney había redefinido también, desde su estudio fílmico, el medio de la animación, llevándolo a niveles insospechados gracias a la experimentación y desarrollo de diversas técnicas que potenciaron el factor expresivo de sus creaciones. Al respecto, puede mencionarse la incorporación temprana de sonido y color; un perfeccionamiento en la interacción entre elementos reales y animados; el desarrollo de innovadoras técnicas para realzar la perspectiva de los paisajes; un acucioso estudio para realzar el movimiento de los personajes; una preocupación por los argumentos y desarrollos dramáticos; o la innovación, con Snow White and the Seven Dwarfs (Cottrell et al. 1937), de incorporar el formato de largometraje dentro del medio de la animación, donde predominaba hasta entonces el cortometraje. Me resulta evidente que todos estos elementos técnicos y expresivos deben haber deslumbrado a los miembros de la OCIAA, ofreciendo un universo de nuevas posibilidades y matices para su retórica propagandística. Fantasía, ternura, humor y diversión, sumados a la reputación de Walt Disney, no solo solaparían un subtexto de propaganda, una vinculación gubernamental o un plan de hegemonía, sino también facilitarían la agenda de la OCIAA al llegar a un público más amplio y diverso, el que abarcaba las audiencias infantiles.

Si bien, según indica Kaufman, no existe ningún registro escrito de la respuesta de Walt Disney al memorándum de su hermano, todo indica que la respuesta afirmativa no solo llegó rápido, sino con una propuesta artística que iba mucho más allá de recrear una "atmósfera sudamericana" en unos cuantos cortometrajes. Disney estaba pensando en algo totalmente nuevo: una serie de producciones animadas, producidas en coordinación con la OCIAA, con auténticos personajes, temas, cultura y música de América Latina (Kaufman 2009: 18).

Ahora bien, más allá de una motivación profesional, se debe tener en cuenta una situación crítica que favorecía a la OCIAA en su negociación para obtener una respuesta favorable de Walt Disney. Por aquel entonces, y a pesar de los éxitos obtenidos, los estudios Disney se encontraban en un difícil momento financiero, tanto por las osadas inversiones destinadas a financiar proyectos fílmicos complejos como por la pérdida momentánea del mercado europeo a consecuencia de la guerra. Por si fuera poco, el descontento de sus trabajadores provocaría, pocos meses después, una agresiva huelga que marcaría un antes y un después en la personalidad del dibujante y la historia de su compañía. De este modo, la oferta de la OCIAA -la que además garantizaba la cobertura de posibles pérdidas de las producciones a realizar en conjunto- constituyó probablemente la única salida para los estudios Disney.

En consecuencia, y luego de algunos meses de negociación ${ }^{6}$, una vez formalizada la alianza los estudios Disney produjeron, entre 1941 y 1945, veintiocho "filmes educacionales" -estos en asociación no solo con entidades gubernamentales estadounidenses, sino también de Canadá- y cerca de ochenta destinados a entrenamiento militar. En lo que respecta a la industria del entretenimiento, el mensaje propagandístico también estuvo presente, en mayor o menor medida, en los más de setenta cortometrajes y seis grandes producciones concebidas en dicho período (Shale 1976: 284-95) ${ }^{7}$. Es precisamente a este último grupo donde pertenecen los dos filmes analizados en este trabajo. El primero de ellos es Saludos

\footnotetext{
6 Según indica Kaufman, el contrato entre ambas partes se firmó en junio de 1941 (2009:18).

7 En relación con la producción propagandística de los estudios Disney durante este período, se sugiere la consulta de Shale (1976) -cuyos apéndices incluyen listados de estas producciones-;
} 
Amigos (Jackson et al. 1942), mediometraje (42') de ficción-documental que alterna animación y realidad compuesto de cuatro cortometrajes ambientados en distintas locaciones de América Latina. Este fue protagonizado en sus pasajes animados por el Pato Donald y el papagayo brasilero José Carioca. El segundo fue The Three Caballeros (Ferguson et al. 1944), el que mantiene la lógica estructural de su predecesor -una secuencia de cortometrajes hilvanados- pero presentando una mayor complejidad técnica y narrativa, extensión de largometraje (71'), un formato predominantemente animado -con inserciones de realidad-y la inclusión de un tercer personaje principal, el gallo mexicano Pancho Pistolas.

En lo que concierne a la literatura académica acerca de estas producciones ${ }^{8}$, puedo comenzar citando trabajos que permiten una mirada más amplia e introductoria a ambos filmes. Entre estos se encuentran la tesis de Ashley Plitong (2013), o bien el artículo de Bernice Nuhfer-Halpen (2011), que de manera más concisa introduce ambos filmes tanto desde una perspectiva contextual como desde su lógica interna, estructural y discursiva. Más allá de las particularidades de cada filme, Neuhfer-Halpen concluye que para ambos se configuró una narrativa con matices educativos y una lógica representacional que, principalmente por medio de la estereotipación, apuntó a la construcción de una imagen de América Latina que tributó a la promoción de la agenda política estadounidense en contexto de guerra.

Un siguiente paso se presenta en el trabajo de Karen S. Goldman (2013). Dotado de una mayor profundidad crítica, la autora aborda ambas producciones desde su lógica imperialista y etnocentrista, así como desde los múltiples recursos - políticos, financieros, técnicos y narrativos- que se conjugaron en una retórica representacional que, al contrario de su intención de disipar los estereotipos de lo latinoamericano propios del cine hollywoodense, más bien los renovaron, reforzando la desigualdad de larga data entre ambas regiones.

De carácter más específico, y centrada en The Three Caballeros, Julianne Burton-Carvajal (1994) desarrolla, a partir de la negación general de un vínculo entre ideología y animación, una lectura que identifica "reiterativas narrativas de conquista en las que el inconsciente patriarcal y el inconsciente imperial se superponen insidiosamente" (1994: 132). En este marco, Burton-Carvajal se centra en el contenido sexual del filme, el que incluye no solo el torpe y persistente acoso de Donald a toda mujer latinoamericana que se le cruce, sino también travestismo, simbología fálica, cruce entre especies y homosexualidad, elementos que, a mi juicio, muchos estudios dejan de lado. En la misma línea -y también centrado en The Three Caballeros-, pero enfocado en problemáticas de construcción de género e imperialismo, se presenta el de José Piedra (1994).

Tomando como referencia los artículos de Burton-Carvajal y Piedra, Eric A. Galm (2008) señala que un filme como The Three Caballeros ha sido estudiado desde perspectivas históricas y de género, mas no desde lo musical, expresión que, a juicio de Galm, resulta muy efectiva para pensar en la construcción de identidades. A partir de esta premisa, el autor aborda, desde el contenido lírico de las canciones contenidas en el filme, la construcción de dos arquetipos de la cultura popular brasilera: el femenino de baiana y el masculino de malandro.

En sintonía con el alegato de Galm relativo a la ausencia de la música en la literatura académica, Carol Hess (2017) desarrolla un profundo y preciso análisis de la música

Cartwright y Goldfarb (1994); Bender (2002); Purcell (2010); y la colección de artículos editada por Van Riper (2011).

8 En complemento con la especificidad de la literatura aquí mencionada, no puedo dejar de reconocer el invaluable marco contextual que me ofrecieron los trabajos de Pennee Bender (2002), Richard Shale (1976), J. B. Kaufman (2009) y Fernando Purcell (2010), así como la perspectiva latinoamericana planteada de manera pionera por Ariel Dorfman y Armand Mattelart (1973). 
contenida en Saludos Amigos en virtud de problematizar la promoción de esta, en el marco de la propaganda de la diplomacia cultural estadounidense, como una muestra de "auténtica" y "genuina" música latinoamericana.

Relacionado también con una propuesta de análisis que incluye lo musical, es relevante citar aquí el trabajo de Elizabeth Berndt Morris y Charles Morris (2011) dedicado al impacto cultural y político de Aquarela do Brasil, cortometraje de cierre de Saludos Amigos concebido a partir de la canción homónima escrita en 1939 por el compositor brasileño Ary Barroso.

Centrado en problemáticas de identidad, particularmente la identidad brasileña por medio del personaje José Carioca, se encuentran los trabajos de Andrew Kelly Nelson (2017) y Sérgio Roberto Massagli (2018). El primero argumenta y legitima la construcción del personaje en cuestión como un "monumento" colonial unificador, portador de referentes de autenticidad. El segundo, en cambio, propone una comprensión crítica del mismo, tanto por su concepción, motivada por intereses políticos, como por los "errores" en su construcción, los que pueden acarrear "efectos deletéreos" en la formación de una identidad cultural nacional.

Desde un enfoque distinto a los anteriores ejemplos, puedo mencionar el texto de J. P. Telotte (2007), el que, reconociendo el tinte colonialista y sexualizado de The Three Caballeros, apuesta más bien por una comprensión de dicho filme a partir de su combinación de imágenes reales y animadas -la denominada Live Action-y el impacto que dicho juego fronterizo provoca en la percepción e interpretación del filme ${ }^{9}$.

Hasta este punto, la literatura académica expuesta ha dado cuenta de una lógica imperialista y etnocentrista de Saludos Amigos y The Three Caballeros, la que, en el marco de la diplomacia cultural y mediante diversos recursos, incidieron en la consolidación, reorientación y renovación de viejos estereotipos de lo latinoamericano. No obstante, a pesar de que en estas producciones la música juega un rol fundamental, tan solo tres de los trabajos mencionados la considera dentro de sus análisis: Galm (2008), Berndt Morris y Morris (2011) y, sobre todo, Hess (2017).

Para responder a lo anterior, este artículo tiene como objeto abordar, a partir de la música contenida en Saludos Amigos y The Three Caballeros, las maneras que esta refuerza el lenguaje propagandístico de buena vecindad y unidad continental contenido en estas producciones. Se opta aquí por la música sosteniendo que este fue uno de los recursos más persuasivos y estratégicos de la propaganda desplegada por el gobierno estadounidense, por medio de la industria fílmica, para apelar a las emocionalidades de las audiencias americanas en pos de un proyecto de hegemonía (Poveda 2019).

Finalmente, es importante indicar que los fragmentos audiovisuales aludidos en este escrito se encuentran disponibles para su consulta ${ }^{10}$.

9 Como complemento a toda la literatura citada, es relevante evidenciar la circulación de una cantidad no menor de ponencias y escritos de estudiantes producidas en el ámbito académico brasileño. Con relación a los trabajos de estudiantes de posgrado, podemos definir aquí una línea de escritos que abordan la temática de manera más introductoria y general (Maccari Ferreira 2007; Rosa 2010), así como otra dedicada de manera más específica a problemáticas de representación e identidad de lo brasileño en estas producciones (Almeida y Muneiro 2012; Bodart 2019).

10 Enlace de acceso: https:/ / 1drv.ms/u/s!Ar-XSjgavuiagawkUMl_XhtCkT1Glg?e=ZuBku0 [acceso: 23 de noviembre de 2021] 


\section{SALUDOS AMIGOSY THE THREE CABALLEROS}

Saludos Amigos y The Three Caballeros son dos filmes producidos en momentos políticos muy distintos. El primero constituye una especie de documental de entretenimiento resultante del viaje que, con apoyo financiero y logístico del gobierno estadounidense, Walt Disney, su esposa y un equipo de dieciséis profesionales -técnicos, productores, publicistas, encargados de negocios y artistas- realizaron entre agosto y octubre de 1941 por diversos países de América Latina. El itinerario, que contempló actividades en Brasil, Uruguay, Argentina, Chile, Bolivia, Perú, Ecuador, Colombia, Panamá, Guatemala y México (Purcell 2010: 510) tuvo como objetivo, muy en el tono de una Política del buen vecino revitalizada en años de guerra, registrar costumbres, festividades locales, danzas y cualquier otra impresión que pudiera servir de material para la producción del filme ${ }^{11}$ (ver Figura 1).

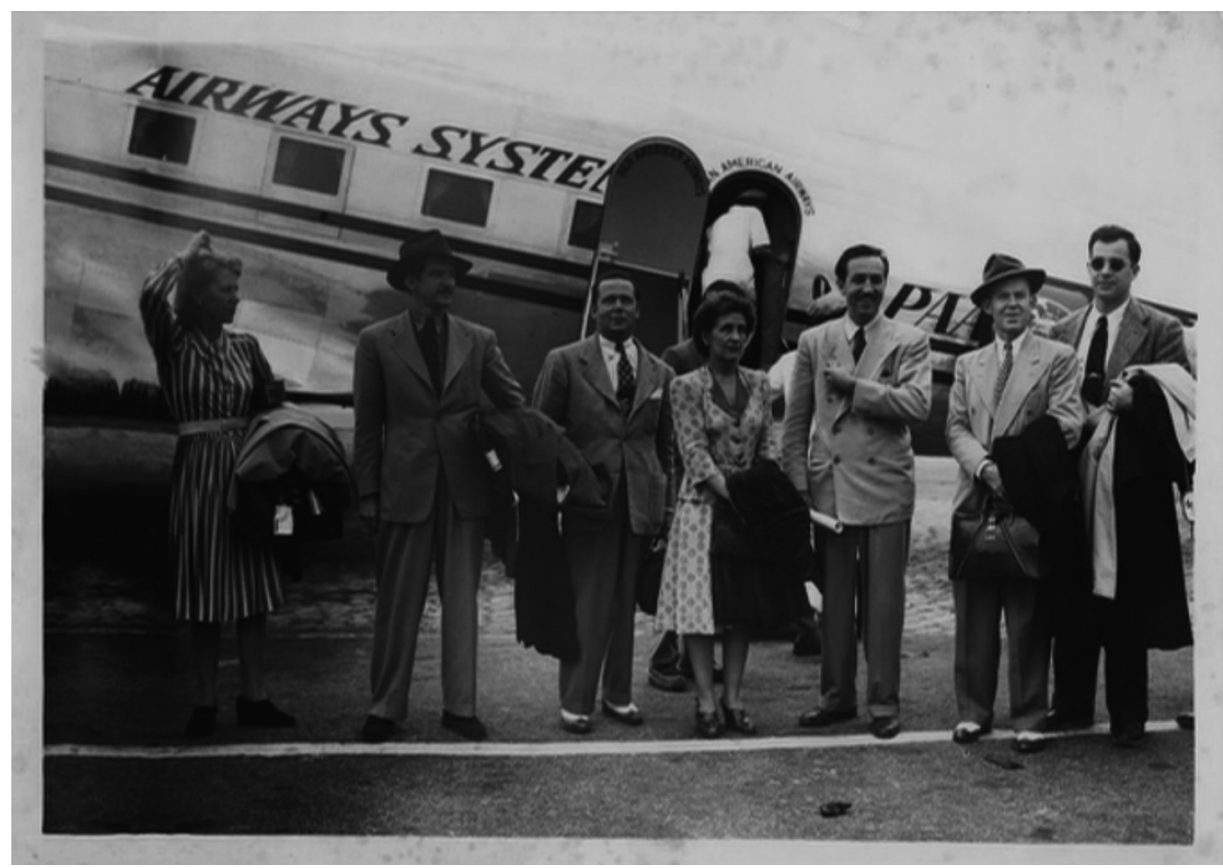

Figura 1: Walt Disney y parte de su equipo arribando a su primera parada, Rio de Janeiro. De izquierda a derecha: Hazel Cottrell, Bill Cottrell, Ted Sears, Lillian Disney, Walt Disney, Norm Ferguson y Frank Thomas. Fotógrafo desconocido. Imagen extraída de Kaufman (2009: 34-35).

11 Es importante indicar que el recorrido de "El Grupo" -denominación coloquial dada a Disney y su equipo durante el viaje por América Latina- es retratado en la producción documental South of the Border, producida el mismo año por los directores Jack Cutting y Norman Ferguson. Asimismo, el viaje en cuestión es recordado varias décadas después por el documental Walt Ẽ El Grupo (2008), dirigido por el estadounidense Theodore Thomas. 
Estrenado en América Latina (Rio de Janeiro) un 24 de agosto de 194212, el filme se compone de cuatro cortometrajes de animación hilvanados por un relato de viaje. Cada uno de estos está dedicado a regiones específicas de América Latina -el lago Titicaca; el paso de Uspallata entre Chile y Argentina, en la cordillera de los Andes; la región pampeana argentina; y una evocación general de Brasil-, alternándose la animación con imágenes reales de algunas de las regiones visitadas, sus capitales, cultura, flora y fauna.

La segunda producción aquí aludida, The Three Caballeros, presenta un contraste importante con su antecesora. En primer lugar, esta se terminó de producir a fines de 194413, momento en el que Estados Unidos ya vislumbraba un exitoso balance de la Segunda Guerra, disminuyéndose la urgencia de una "buena vecindad" y abriéndose, en consecuencia, un mayor espacio a la fantasía e imaginación en lo que refiere a las representaciones de Latinoamérica desde su industria fílmica. En segundo lugar, era México la nación que ahora interesaba resaltar en el filme, esto a diferencia de Argentina y Brasil, ensalzadas en Saludos Amigos, pero ahora disminuidas. Finalmente, este filme presenta una mayor complejidad en varias de sus características. Si bien este mantiene la lógica estructural de cuatro cortometrajes hilvanados -esta vez no por un relato de viaje, sino por la apertura de "regalos" que Donald recibe de sus amigos latinoamericanos, los que configuran un recorrido que comprende el Polo sur, la pampa argentina, el estado de Bahía, y una compleja sección de ocho partes dedicada a México-, se constata aquí un crescendo de intensidad, sexualización y caos que no se detiene sino hasta el final de la producción (ver Figura 2).

En ambas producciones, la música jugó un rol muy importante. $\mathrm{Al}$ respecto, las ideas de R. S. Carr, ejecutivo de los estudios Disney, resultan reveladoras. En un documento de cuarenta páginas elaborado en febrero de 1942 y titulado "Ideas para un nuevo programa fílmico en Sudamérica”, Carr señala que las películas de Disney para el Cono Sur debían ser "completamente diferentes respecto de los otros tipos de propaganda" enviadas a la región. Siendo la animación un "medio mágico", añade, "este está dotado de un "profundo potencial para evocar sentimientos y sobrecogimiento. 'Ave María' en Fantasia fue solo el comienzo. Nosotros debemos aprovechar por completo esta cualidad en muchas de las películas propuestas creando un sentimiento religioso profundo, asociándolo con ideales políticos". Más adelante, Carr sostiene también que "el valor propagandístico de las impresiones audiovisuales $[\ldots]$ es muy alto, debido a que estandariza las ideas al darle al espectador una imagen visual ya armada, antes de que se ponga a pensar y la interprete por sí mismo". En esta idea probablemente acertada de una audiencia pasiva -esto tomando en cuenta el asombro que deben haber producido este tipo de filmes-, el autor atribuía una importancia a la música en relación con su "alta efectividad de jingles, versos y canciones que han sido valoradas por quienes moldean las mentes del público". Este potencial obligaba, según Carr, a no escoger simplemente música "apropiada", sino también a componer música pensada "conscientemente como parte de la propaganda" (Citado en Purcell 2010: 515).

La atención puesta por Carr a la música como un arma eficaz para esta, en término de Rockefeller, "guerra sicológica" (Citado en Bender 2002: 92), estaba en sintonía no solo con la aplicación sistemática de ciertos recursos y procedimientos musicales que eran

12 Luego de su estreno en Brasil, el filme fue exhibido por primera vez en Argentina (Buenos Aires) el 6 de octubre de ese año. El estreno en Estados Unidos se programó para el año siguiente, específicamente el 6 de febrero, en la ciudad de Boston (Kaufman 2009: 272). Para un mayor detalle técnico de ambas producciones, se recomienda la revisión del Apéndice A (puntos IA y IB) ofrecido por Kaufman (2009: 272-82).

13 El filme es estrenado el 21 de diciembre de 1944 en Ciudad de México. Su estreno en Estados Unidos se produce en la ciudad de Nueva York el 3 de febrero del siguiente año (Kaufman, 2009, p. 275). 

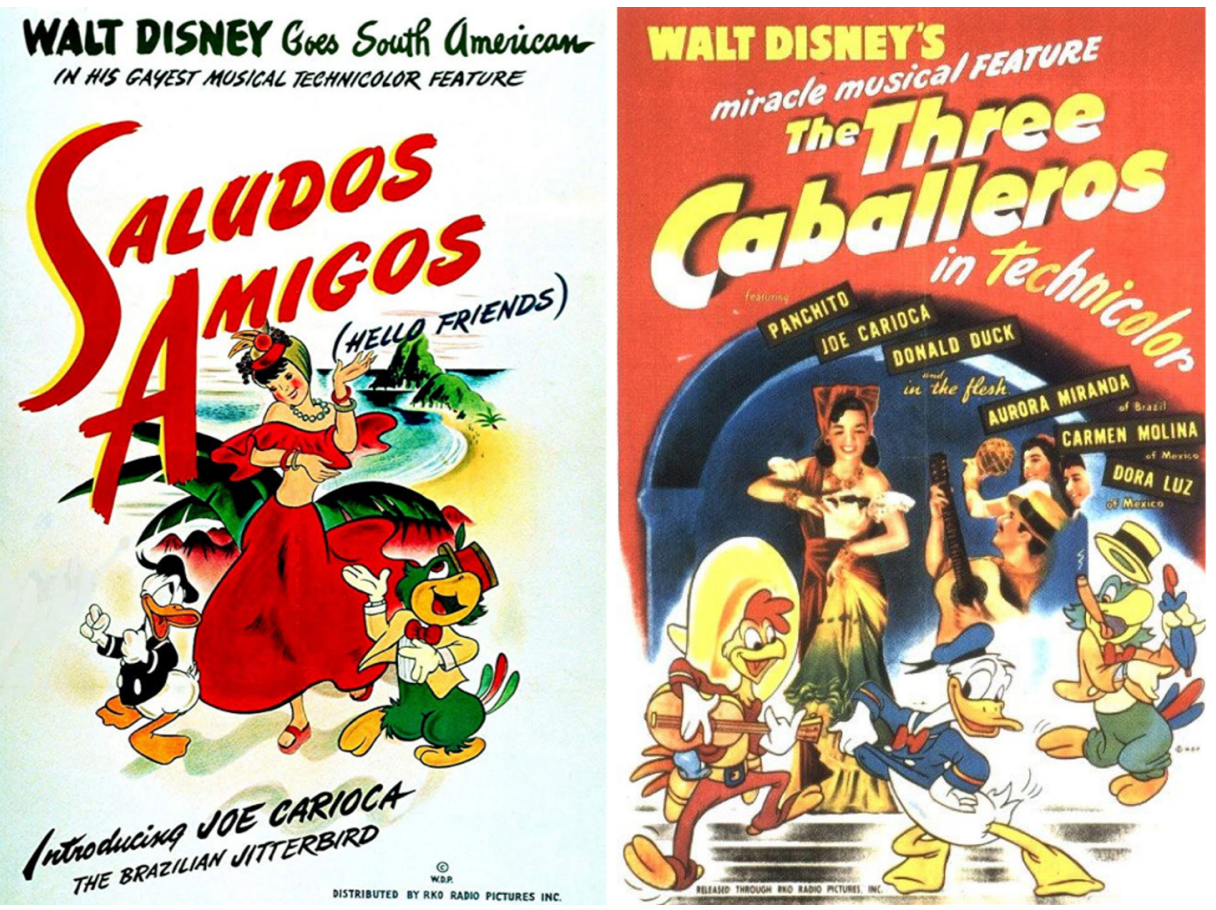

Figura 2: Walt Disney Goes South America. Afiches publicitarios de Saludos Amigos y The Three Caballeros. Imágenes extraídas de Kaufman (2009), páginas 70 y 182, respectivamente.

empleados en cualquier filme destinado a propagar un mensaje de buena vecindad, sino también con las agencias fílmicas y gubernamentales comprometidas en su producción ${ }^{14}$.

El equipo a cargo de la música de ambas producciones estuvo compuesto por Edward "Ed" Plumb (1907-1958) ${ }^{15}$, Paul J. Smith (1906-1985) ${ }^{16}$ y Charles Wolcott (1906-1987) ${ }^{17}$ (ver Figura 3), este último como director musical y único músico del equipo que acompañó a Walt Disney en su viaje por América Latina. En consecuencia, asumimos a Wolcott como el principal receptor y administrador de las impresiones musicales que se recabaron durante el viaje, siendo estas materializadas e incorporadas en Saludos Amigos y luego en The Three Caballeros desde su condición de director musical.

14 Para profundizar en este punto, se sugiere la revisión del trabajo de Juan Carlos Poveda (2019).

15 Compositor estadounidense. En 1930 se trasladó a California para trabajar como músico en la industria fílmica. En sus años como compositor en los estudios de Walt Disney, participó como director musical de Fantasia (1940), y compositor en Bambi (1942), entre otras.

16 Compositor estadounidense que ocupó gran parte de su carrera trabajando para los estudios de Walt Disney. Entre los numerosos filmes para los cuales colaboró en dicho estudio, figuran Snow White and the Seven Dwarfs (1937), Pinnochio (1940), Fantasia (1940) y Cinderella (1950).

17 Compositor estadounidense. Hacia mediados de los años treinta se radicó en Hollywood y desde 1937 comenzó a trabajar para los estudios de Walt Disney. En dicho lugar participó en exitosas producciones como Snow White and the Seven Dwarfs (1937), Pinnocchio (1940), Bambi (1942), entre otras, llegando a ocupar, hacia 1944, el puesto de Director Musical General hasta su traslado, en 1950, a Metro Goldwyn Mayer. 


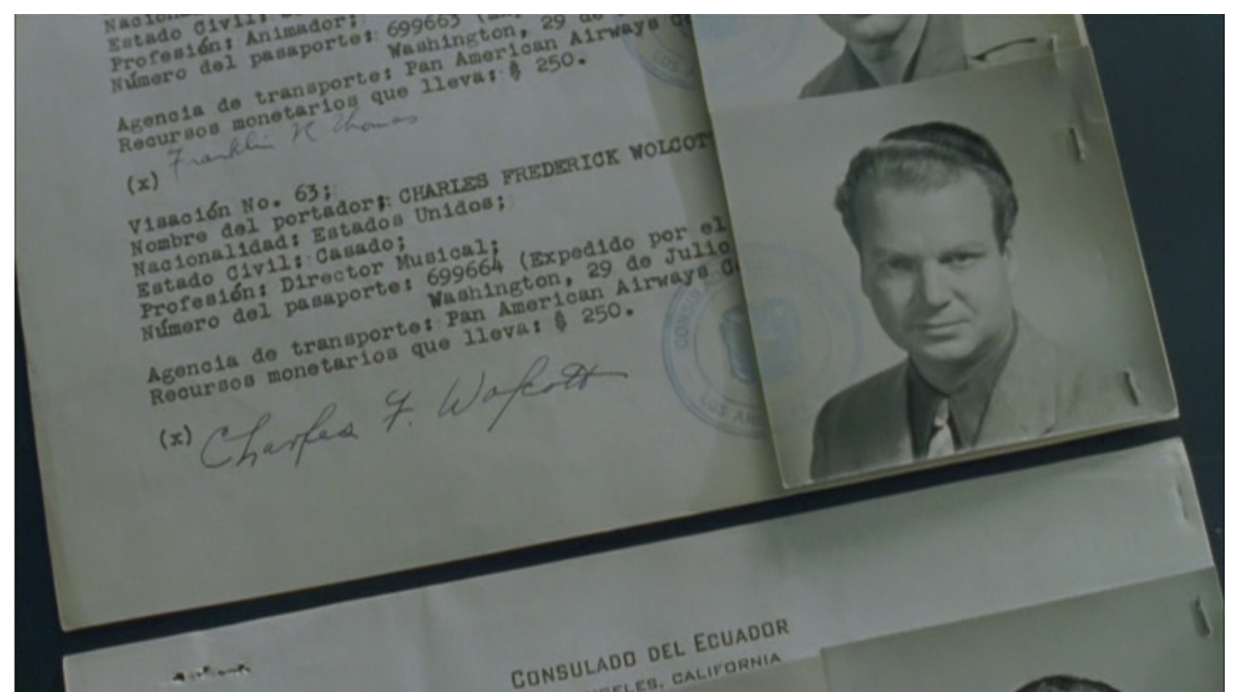

Figura 3: Permiso de entrada de "El Grupo" a Ecuador. Detalle de Charles Wolcott. Imagen extraída de Walt Eं El Grupo (Thomas 2008).

Es importante mencionar que ambos filmes fueron nominados al Oscar en las categorías mejor música original y mejor sonido, y por mejor canción original en el caso de Saludos Amigos $^{18}$. Además, como ya empezaba a ser habitual en las estrategias de marketing de Disney, también se lanzaron producciones fonográficas con la música de ambas producciones, lo que diversificó sus medios y formas de circulación (ver Figura 4).

\section{EL CORRELATO MUSICAL DE LA BUENA VECINDAD}

Saludos Amigos
A fond greeting to you

A warm handshake or two

Good friends always do.

Saludos amigos

A new day's waiting to start You must meet it, wake up and greet it

With a gay song in your heart

\section{Hello Friends, cantemos}

Salud, fraternidad

Ya es hora de vivir

en buena amistad.

Hello Friends, vecinos

unidos hay que estar

El sol nace en un nuevo día

Que nos trae felicidad ${ }^{19}$.

Un esfuerzo importante de la propaganda de la buena vecindad estuvo puesto en retratar aspectos de América Latina tales como su geografía, costumbres, monumentos, pueblos

18 https://www.oscars.org/oscars/ceremonies/1944 y https://www.oscars.org/oscars/ ceremonies/1946 [acceso: 5 de febrero de 2021]

19 Lírica de "Saludos Amigos", canción principal del filme escrita por Charles Wolcott con texto de Ned Washington, en su versión para las audiencias estadounidenses (izquierda) y para su distribución en Latinoamérica (derecha) [Ver clip $\mathrm{N}^{\circ} 1$ ]. 

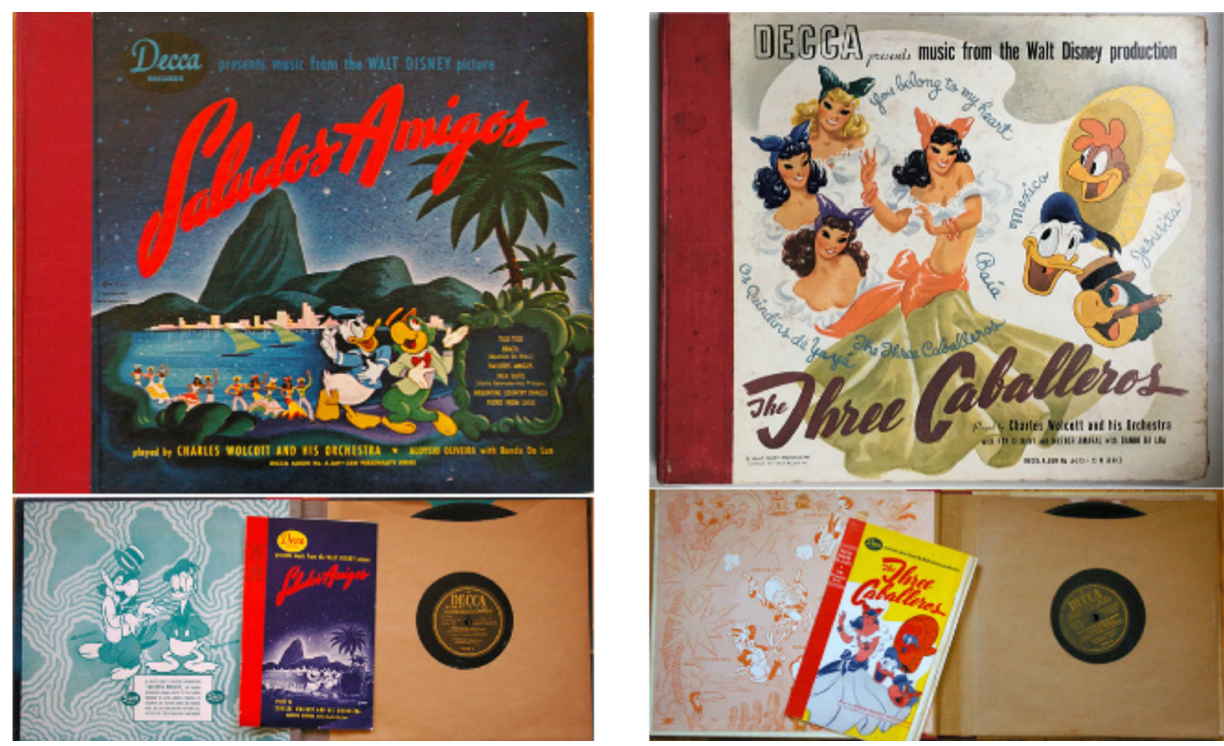

Figura 4: Presentación en tres discos de 10 pulgadas ( $78 \mathrm{rpm}$ ) de la música de cada filme

(Decca Records, $\mathrm{N}^{\circ} \mathrm{A}-369$ y N $\left.{ }^{\circ} \mathrm{A}-373\right)$.

y ciudades, festividades, entre otros; esto a modo de promoción turística y cultural de la región, así como de oferta de un producto, por así decirlo, "genuinamente" latinoamericano. Si bien dicho procedimiento fue desarrollado con mayor profundidad e intención documental en una gran cantidad de corto y mediometrajes educativos producidos por el gobierno estadounidense, fue finalmente el cine de ficción el medio más efectivo para transmitir un mensaje que, en el fondo, tenía un carácter propagandístico.

Un excelente ejemplo de lo recién expuesto es Saludos Amigos, filme que en esencia constituye un Travel Talk ${ }^{20}$ desde una perspectiva Disney y cuya narrativa pedagógica, fronteriza entre lo ficcional y lo documental, se refleja en la musicalización de cada una de las regiones aludidas.

Es así como, desde su primera parada en el lago Titicaca, las imágenes de paisajes y la actividad social y económica en torno al mismo son musicalizadas con una versión instrumental de "Saludos Amigos" que evoca una idea de lo incaico mediante lo tímbrico -asignando la melodía principal a dos quenas e incorporando un glissando ascendente y descendente en un instrumento de viento que emula una zampoña- y lo melódico -adaptando la melodía a una escala pentáfona ${ }^{21}-$. Luego es un flautín el que interpreta la melodía -también pentáfona- de "Llama Serenade", composición instrumental que junto con "Inca Princess" forman los dos movimientos de la Inca Suite, escrita por Charles Wolcott para el filme. Estas músicas dialogan con imágenes reales y animadas de músicos locales (ver Figura 5) y obedecen, en palabras del narrador del filme -Fred Shields en la versión

20 Serie de cortometrajes documentales acerca de distintas ciudades y regiones del globo dirigida por James Fitzpatrick. Estos filmes fueron producidos durante las décadas del treinta al cincuenta por la Metro-Goldwyn-Mayer y fueron utilizados -y patrocinados- con fines diplomáticos y turísticos.

21 Respecto de la pentafonía y su rol en las construcciones y representaciones de lo andino, se recomienda la consulta de Mendivil (2012). 
en inglés y Alberto Soria en la castellana-, a una música "extraña y exótica", construida por esta cultura a base de "melodías heredadas de sus ancestros incas" [Ver Clip No 2].
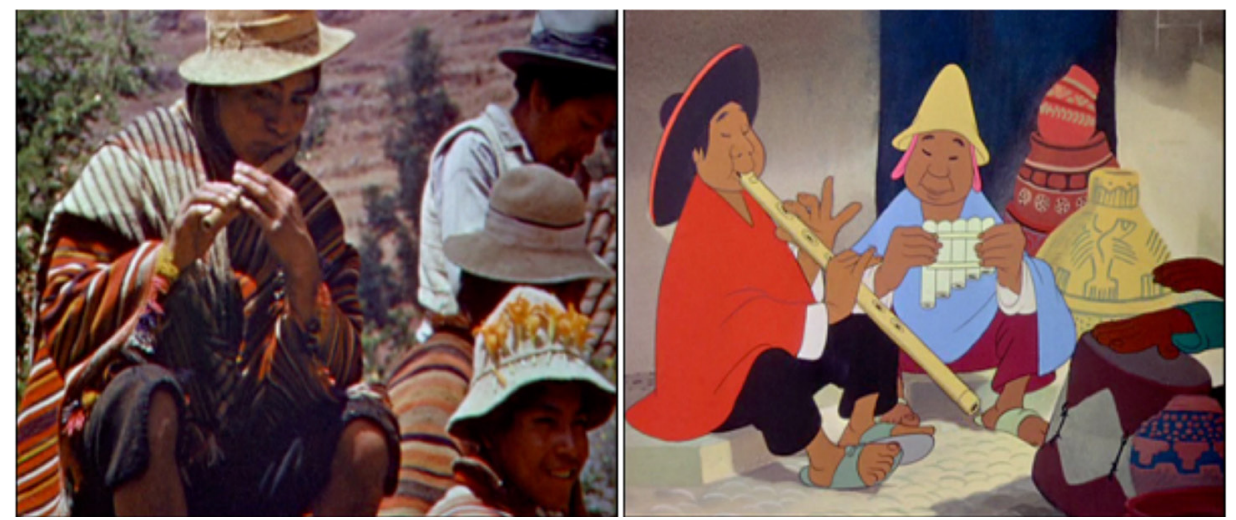

Figura 5: Adolescente ejecutando un Pitu (flauta traversa andina) y una representación animada de músicos locales en Saludos Amigos.

Luego del cortometraje dedicado al Titicaca, se produce un breve paso por Chile 22 musicalizado con la composición instrumental "Pedro from Chile", escrita por Paul J. Smith sobre el esquema rítmico de la tonada y utilizando la guitarra y el contrabajo en la base rítmica, pero entregando la melodía a los violines y trompetas, instrumentos lejanos a la sonoridad de la tradición musical del Chile Central. A causa de que Smith no estuvo en el viaje por América Latina, se asume que compuso "Pedro from Chile" con los apuntes y sugerencias de Wolcott ${ }^{23}$.

De mayor énfasis pedagógico resulta la narración del paso por Argentina, la que, luego de unas breves y adulatorias imágenes de una moderna Buenos Aires -musicalizadas con una versión de "Saludos Amigos" con influencias de milonga y la participación de un acordeón-, retoma el interés por lo rural y el relato se enfoca en la región pampeana. Aquí, el equipo de Disney es invitado al estudio y hacienda de Florencio Molina Campos, dibujante especializado en retratar la cultura gaucha en un estilo que sincronizaba muy bien con las expectativas de los visitantes. La música que acompaña estas vivencias es otra composición instrumental, "Argentine Country Dances". Esta fue escrita por el otro compositor del filme, Edward Plumb, también probablemente desde la información otorgada

22 Para profundizar en la polémica y el malestar surgido en Chile por la no inclusión de imágenes reales en el filme, consultar Purcell (2010). En adición, es oportuno indicar que la motivación de incluir un avión "niño" como protagonista de este segundo cortometraje fue parte del agradecimiento ofrecido a la Pan American Airways por el apoyo logístico prestado al mencionado viaje del equipo de Disney por Latinoamérica (Kaufman 2009: 20-22).

23 Según afirma Disney en una entrevista para la televisión canadiense, el paso por Chile era, junto con Argentina y Brasil, uno de los tres más importantes que le solicitó el gobierno (Thomas 2008). No obstante, el material recopilado en el país al parecer no cumplió con las expectativas del espectáculo hollywoodense, dejando parte del material filmado para ser incluido, más bien, en el documental South of the Border, donde puede verse el encuentro de Disney con un conjunto folclórico en una propiedad -"fundo"- particular [Ver Clip No 3]. 
por Wolcott a partir del encuentro, en la hacienda de Molina Campos, con "un grupo de diestros bailarines [que] actuaron para ellos. No el tango moderno de Buenos Aires, sino las danzas folclóricas de Argentina. Las mismas melodías que bailaron sus abuelos". Con relación a la documentación acerca de música y danzas tradicionales, resultó fundamental el encuentro sostenido en el Alvear Palace Hotel con la Compañía de Arte Nativo, dirigida por el ya legendario folclorista Andrés Chazarreta (1876-1960). Este encuentro no se incluyó en el filme, mas sí en South of the Border [Ver clip No 4]. Las secuencias con imágenes reales del paso por Argentina se complementan con el tercer cortometraje animado del filme, "El Gaucho Goofy", lleno de explicaciones, en un tono humorístico, acerca de la indumentaria y costumbres del gaucho, destacándose su similitud al cowboy estadounidense. Destacan, en términos musicales, las escenas "pedagógicas" de Goofy bailando chacarera, malambo y pala pala, así como su entonación fallida de "Yo soy la blanca paloma" -canción tradicional del género triste, recopilada por Chazarreta (Hess 2017: 116) - a la luz de la luna.

Luego de los tres retratos recién presentados -todos de carácter predominantemente rural- se da paso al cuarto y último cortometraje del filme. Este, dedicado a Brasil, se inicia con imágenes icónicas de Rio de Janeiro -Pan de Azúcar, playa de Copacabana, Corcovado y diversas capturas de la ciudad-, todo musicalizado con una versión instrumental de "Saludos Amigos" en su estilo original, derivado del one step ${ }^{24}$.

En términos musicales, Rio de Janeiro - que fue el primer territorio latinoamericano en el que aterrizaron Walt Disney y su equipo- ofreció recursos que estaban muy en sintonía con las expectativas hollywoodenses: alegría, baile, carnaval, ritmos festivos y seductores e instrumentos llamativos. Es así como podemos ver en el filme a El Grupo recibiendo lecciones de cómo ejecutar y bailar samba, evidenciándose otro procedimiento fílmico muy propio de una narrativa pedagógica: el encuadre en primer plano de instrumentos musicales locales [Ver Clip $\mathrm{N}^{\circ} 5$ ].
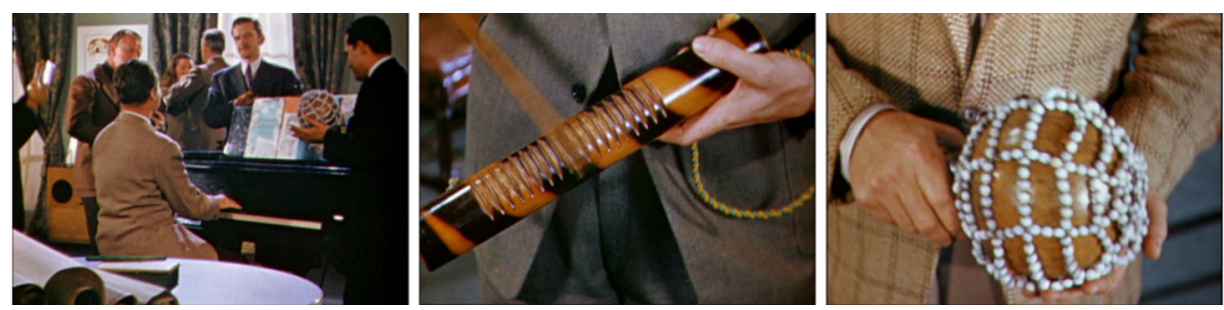

Figura 6: Imágenes de Saludos Amigos que retratan al equipo de Disney experimentando la samba con Wolcott al piano, oportunidad para unos primeros planos al reco reco y a lo que el narrador denomina como una cabasa.

Para finalizar este paso por Brasil, se ofrece un cuarto cortometraje animado -que además cierra el filme- en donde la animación se pone al servicio de una canción latinoamericana: "Aquarela do Brasil”, de Ary Barroso. Dicha sección pone en práctica otros

24 Tal como indican González y Rolle 2004, "el one-step es una marcha rápida en dos tiempos de división binaria $(2 / 4)$ o ternaria (6/8), que recibe influencias del ragtime, expresadas en las síncopas del acompañamiento y la melodía, y sus acentos en los tiempos débiles. Perdida su vigencia como baile, el one-step continuó vigente como marcha sincopada en la música popular orquestal" (González y Rolle 2004: 645). 
recursos de buena vecindad musical, tales como la incorporación de músicos y agrupaciones latinoamericanas en escena, el uso -acreditado- de repertorio musical latinoamericano de diversas tradiciones, así como el lucimiento de varios instrumentos y conformaciones instrumentales de la región aludida. Esto se refleja en la presentación que hace el narrador de "Aquarela do Brasil", su autor y el cantante que la interpreta para el filme, Aloysio Oliveira, miembro en estos años de la agrupación Bando da Lua, la que acompañaba a Carmen Miranda en su intenso paso por Hollywood. Otro éxito aquí utilizado -y acreditado al inicio de la secuencia- es "Tico Tico no Fubá", de Zequínha de Abreu, canción que se presenta en formato instrumental para el momento en el que el personaje local, el malandro José "Pepe" Carioca, le explica a Donald -luego de abrazarlo con efusividad, admiración y sentido de buena vecindad- lo que es una samba. Este ritmo no resulta fácil para Donald, hasta el momento en que se emborracha con cachaça [Ver resumen de secuencia en Clip $\mathrm{N}^{\circ}$ 6].

Recursos como los descritos anteriormente se intensifican en The Three Caballeros, cuya producción contempló la participación de artistas latinoamericanos como Aurora Miranda, Aloysio de Oliveira, Dora Luz, la bailarina Carmen Molina o el barítono Carlos Ramírez -quien no figura en pantalla- y las agrupaciones Bando da Lua, Padua Hills Players, Trío Calaveras y Trío Ascencio del Río. Asimismo, se incorporaron nuevos géneros -corrido, son jarocho y bolero-; se diversificó la gama de instrumentos (ver Figura 7) y conformaciones instrumentales -mariachi, conjunto jarocho (aquí con una conformación tradicional de requinto, jarana, arpa, violín y, para este caso, de un contrabajo), trío de boleros, conjunto de marimbas, conjuntos de choros-y se amplió el repertorio con canciones como "Você já foi à Bahia?" de Dorival Caymmi -adaptada al inglés con textos de Norm Ferguson-, "Na baixa do sapateiro" y "Os quindins de Yayá” de Ary Barroso, una adaptación de “¡Ay, Jalisco, no te rajes!" de Manuel Esperón y letra de Ernesto Cortázar como canción principal del filme, o bien, "Solamente una vez" de Agustín Lara, que en el filme figura en una adaptación del letrista Ray Gilbert al inglés ("You Belong to My Heart") y provocó un gran impacto en la industria musical estadounidense.
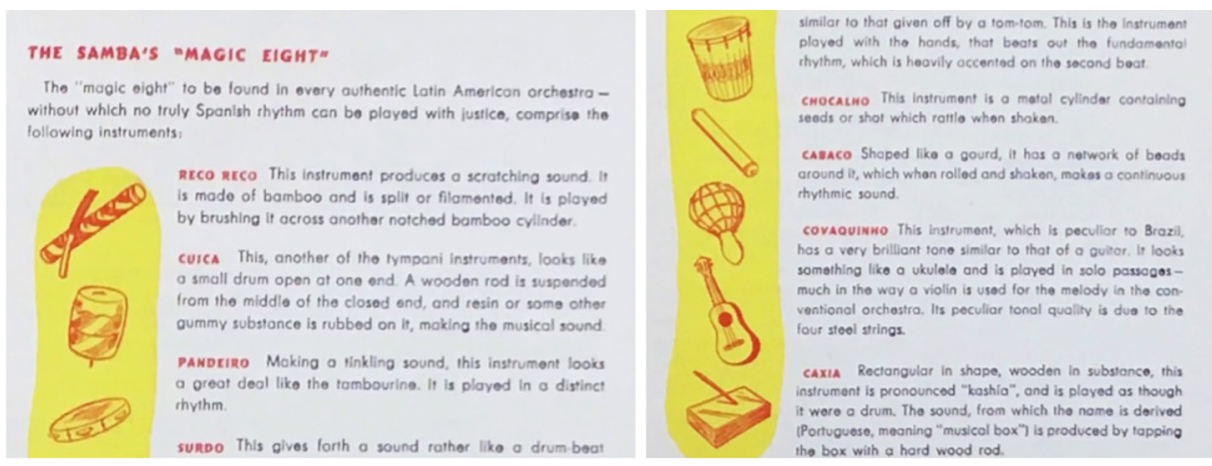

Figura 7: Recuadro ilustrativo y pedagógico de instrumentos utilizados en la ejecución de samba incluido en el cuadernillo de la producción fonográfica de The Three Caballeros.

En virtud del mencionado ánimo pedagógico de la buena vecindad, también resultaron frecuentes escenas de carácter, por así decirlo, inofensivo y pintoresco de fiestas populares tales como carnavales, fiestas campesinas, bodas de pueblo y similares, en las que también la música jugó un rol muy importante. Ejemplo de esto son las escenas reales del Carnaval de Rio en Saludos Amigos o las representaciones animadas en The Three Caballeros de una 
"Fiesta y Carrera [de caballos]", donde gauchos bailan "felices" "zamba y gato" y "derrochan sus pesos en apuestas"; o, ya en México, de la celebración de la Natividad con la tradición de Las Posadas y de fiestas campesinas donde se baila jarabe pateño o son jarocho, estas últimas combinando ya animación y realidad.

Ahora bien, otro procedimiento musical que resulta muy recurrente -y para mí muy significativo- en las producciones de buena vecindad fue la alternancia y fusión de estilos musicales estadounidenses y latinoamericanos con sus consecuentes danzas e idiomas. Me refiero aquí a secuencias musicales en las que, por ejemplo, una canción es interpretada alternando o fusionando géneros musicales estadounidenses y latinoamericanos, por ejemplo, foxtrot y samba. En términos dancísticos, esto se traduce en coreografías individuales y conjuntas que aplican el mismo principio -alternancia o fusión, por ejemplo, de pasos de tap y tango-. Asimismo, estas canciones son interpretadas por personajes estadounidenses y latinoamericanos, con sus consecuentes juegos con el idioma. Este procedimiento habría simbolizado desde lo musical, a mi juicio, un diálogo e intercambio amistoso y supuestamente horizontal entre la cultura estadounidense y la latinoamericana. Ejemplos de este procedimiento pueden verse y escucharse en la secuencia explicativa acerca de danzas argentinas del corto "El Gaucho Goofy", cuando la chacarera es bailada con pasos de bunny hug -estilo de baile popular originado en la costa oeste hacia comienzos de siglo-y una alusión a la performance de la entonces popular canción "Jumpin Jive" (escrita en 1939 por Cab Calloway, Frank Froeba y Jack Palmer) o el malambo es ejecutado al piano evocando estilos populares afroamericanos. Asimismo, se constata este procedimiento cuando Goofy, primero en calidad de cowboy, es musicalizado con una versión de la canción popular mexicana "La cucaracha" en un estilo country. Luego, cuando ya está caracterizado como gaucho, es "retornado" a Texas, volverá a sonar "La cucaracha", pero en estilo foxtrot [Ver resumen de secuencia en Clip $\mathrm{N}^{\circ} 7$ ].

Otro ejemplo puede verse en la secuencia ambientada en Veracruz donde se interpreta el son jarocho "Lilongo" (escrito por Felipe "El Charro" Gil), el que es danzado torpemente por Donald, quien luego se luce al momento que esta se ejecuta en un boogie beat con una presencia destacada del contrabajo -instrumento que asumo resulta ajeno a la entonces tradición musical veracruzana- ejecutado con naturalidad por el personaje latinoamericano José Carioca. Luego de un breve pasaje en estilo de samba y otro en un "estilo estadounidense", se retorna al estilo de son jarocho, ahora dominado por Donald [Ver resumen de secuencia en Clip $\mathrm{N}^{\circ}$ 8]. No obstante, el ejemplo de este procedimiento donde a mi parecer resulta más evidente la poca horizontalidad de este diálogo entre Estados Unidos y América Latina se produce en Saludos Amigos, en el corto "Lake Titicaca". Me refiero a la secuencia en la que se muestra a un niño de la zona que domina a su llama mediante el toque de una home-made flute (quena). La secuencia, que juega con el material melódico de "Llama Serenade" de Wolcott, muestra a un Donald turista que, luego de intercambiar su indumentaria con su nuevo amigo andino, intenta fallidamente ejecutar la quena, provocando no solo su enojo, sino el de la llama. El panorama cambia abruptamente cuando Donald comienza a ejecutar una variante de la melodía en un estilo más ágil, un rápido foxtrot con la sonoridad de la orquesta del estudio, provocando movimientos que el animal no puede dominar. Esta escena es interpretada por Goldman como una apropiación cultural "no amenazante" del "otro exótico", en el que el citado fragmento musical "inca" es "americanizado" por el estadounidense, convirtiéndolo finalmente en un producto de consumo para las audiencias de Hollywood, esto a modo de simbología del sistema capitalista (2013: 32). En adición, la secuencia se cierra con Donald dominando no solo el instrumento, sino también la llama del niño, con la que continuará su aventura en la secuencia siguiente [Ver Clip $\mathrm{N}^{\circ}$ 9]. 


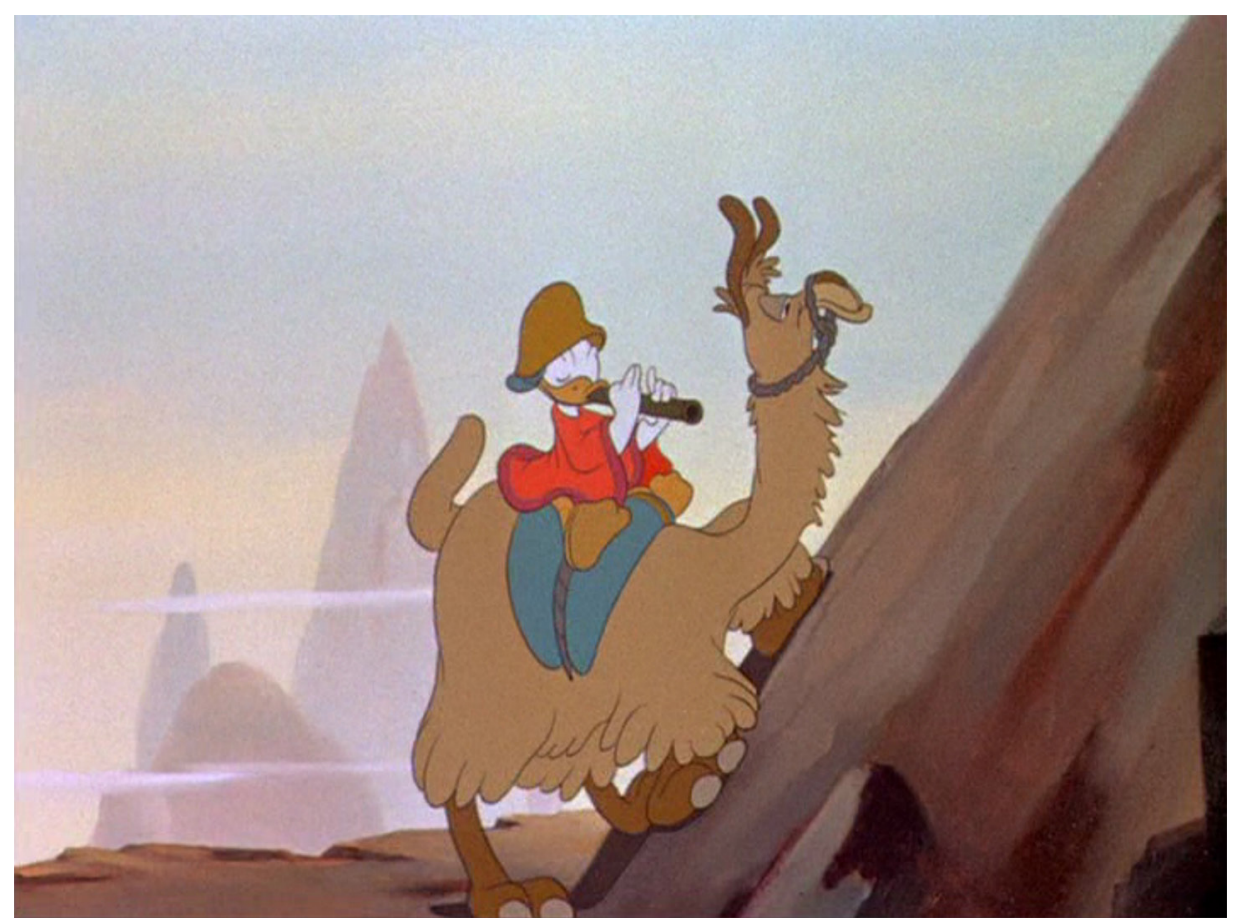

Figura 8: El turista estadounidense vistiendo un atuendo vernáculo, ejecutando un instrumento musical vernáculo y dominando un animal vernáculo en Saludos Amigos.

\section{BULLICIO, SEXUALIZACIÓN Y CAOS EN LAS REPRESENTACIONES DE LO LATINOAMERICANO}

“¿Han visto alguna a vez a un trabajador tan rápido?”25

Si bien algunos trabajos mencionados al inicio de este artículo han estudiado diversos aspectos de la sexualidad implícita en The Three Caballeros, mi interés está puesto en un plano más explícito. Me refiero a la persistente sexualización y acoso de la mujer latinoamericana, la que es representada aquí como un objeto de constante deseo y conquista, sobre todo para el viajero estadounidense "personificado" en Donald. Este recurso, que no resulta habitual en las producciones de Disney del período y menos en los códigos culturales relacionados con la infancia, está presente, no obstante, en la narrativa de innumerables filmes de ficción de Hollywood acerca de América Latina del período, donde la música latinoamericana actúa como un poderoso afrodisíaco que seduce incluso a los personajes más rígidos (Poveda 2019: 142). Es precisamente esta línea en la que se enmarca Disney.

La aparición de una sexualización más evidente en The Three Caballeros comienza a aparecer poco antes de la mitad del filme, momento en el Donald es invitado por José

25 "Did you ever see such a fast worker?" (José Carioca ensalzando el constante y desesperado esfuerzo de Donald por "conquistar" a una mujer en The Three Caballeros). 
Carioca a conocer Bahia ingresando en un libro mágico -uno de los regalos enviados desde América Latina para Donald- que los transporta a una representación animada de dicha ciudad $^{26}$. En estas escenas se escucha desde un comienzo una voz femenina que entona la samba-canción de Barroso "Os Quindis de Yayá". A los pocos segundos, se advierte que dicha voz pertenece a Yayá, una alegre y atractiva baiana (Aurora Miranda) que carga sobre su cabeza una bandeja con quindis - golosina tradicional de la zona-. Ella es, a lo largo de la secuencia, acosada por numerosos malandras ${ }^{27}$, y, desde un inicio, por Donald, quien se ofusca cada vez que aparece un adversario en su intención de conquista.

La música ocupada para describir esta situación resulta totalmente distinta a lo escuchado hasta ese momento del filme. A los pocos segundos de escucharse a Aurora Miranda cantar "Os Quindis de Yayá" -mientras Donald y José Carioca corren a esconderse para esperar que ella pase- se integra un leve toque de tambor grave. Una vez que ella aparece en escena, y se comprueba lo atractiva que es, se suman unas semillas -probablemente una cabasa-. A medida que transcurre la acción, al pregón melódico de "Os Quindis de Yayá" se van incorporando diversos instrumentos de percusión ejecutando un ritmo de samba, hasta el momento en que se inicia la interpretación regular de dicha canción. Interesante resulta la conclusión de la secuencia: Donald, aprovechando que la baiana se queda sola, le ofrece un ramo de flores, recibiendo, a modo de agradecimiento, un beso que lo deja en un estado de placer y ensoñación. Este estado -que reaparece en lo que queda del filme, de manera cada vez más intensa- es musicalizado nuevamente con instrumentos de percusión, los que además figuran ilustrados, bailando y ejecutando un ritmo de samba [Ver resumen de secuencia en Clip $\left.\mathrm{N}^{\circ} 10\right]$.

Es importante notar que esta musicalización de escenas de carácter más erótico con percusiones afrolatinas potenció escenas de baile en las que la relación entre sexualidad, exotismo y una suerte de primitivismo constituyeron factores de una fórmula muy apta para las narrativas de lo latino en Hollywood (ver Figura 9).

Luego del "regalo" de Brasil, Donald abre el proveniente de México, país protagonista del filme, al que se le dedica prácticamente la mitad de su duración. Dentro de este regalo figura el nuevo personaje, el tercer caballero Pancho Pistolas, el que retomará la canción principal del filme, una adaptación del corrido de Manuel Esperón “¡Ay, Jalisco, no te rajes!”, popularizado en 1941 por Jorge Negrete en un filme mexicano con el mismo nombre. Considerando el éxito de la canción, Disney la adaptó al inglés, versión que quedó a cargo del letrista del estudio, Ray Gilbert. Así, en lugar del texto original de Ernesto Cortázar -el que básicamente expresa una admiración hacia el estado de Jalisco, su capital, Guadalajara y las mujeres de esta localidad-, el texto adaptado gira en torno a la amistad de los "tres caballeros", "tres tipos felices, con fuertes sarapes" que, vayan donde vayan, "siempre unidos" van a estar. Ahora bien, el recurso de sexualización aparece cuando se indica que si aparece alguna "belleza [latina] diciendo sí, no o quizás", el sentido de unión y amistad se disuelve, pues en ese caso "cada uno corre por su propia cuenta" 28 .

26 A diferencia de Saludos Amigos, las imágenes reales en este filme provienen solo de diversas localidades de México.

27 Es admisible indicar que los malandras que figuran con instrumentos musicales son miembros de Bando da Lua. Entre ellos, irrumpe Nestor Amaral actuando como un vendedor de naranjas que interpreta una canción de carácter más pausado, "Pregões Cariocas", del compositor Carlos Alberto Ferreira Braga, también conocido como Braghinha o con el seudónimo João de Barro.

28 "We're three happy chappies/ With snappy serapes/ (...) When Latin baby says yes, no or maybe/ Each man is for himself". 

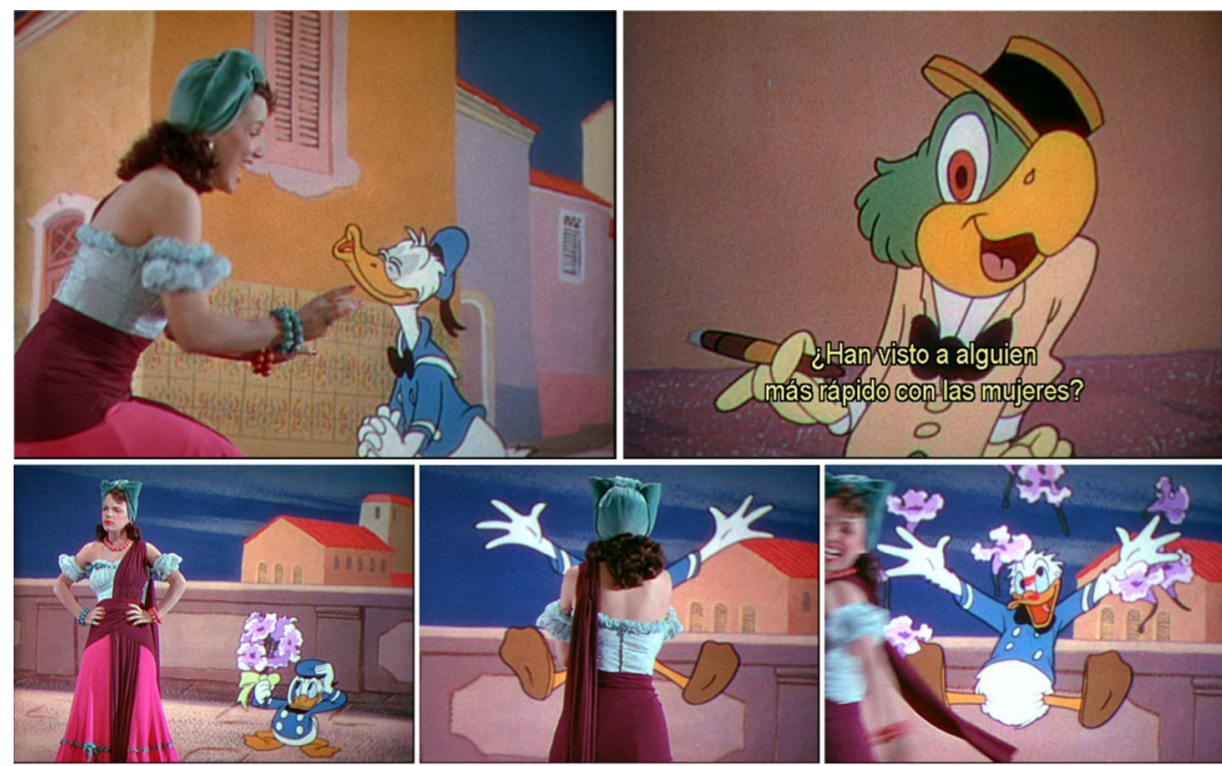

Figura 9: Donald en The Three Caballeros viviendo su primer encuentro con una mujer latina, la baiana Yayá (Aurora Miranda).
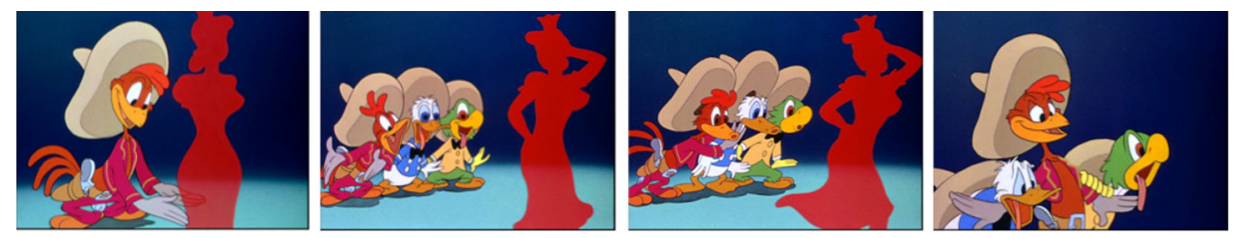

Figura 10: Los tres caballeros reaccionando frente a lo que en su canción principal denominan como una "Latin baby".

Luego de esta suerte de declaración de principios, se inicia una larga secuencia que, en la medida que avanza, aumenta en complejidad, alusiones sexuales, caos y sicodelia. Así, en el inicio de esta, podemos ver a los tres caballeros emprendiendo vuelo arriba de un sarape hacia el balneario de Acapulco. Una vez en el lugar, Pancho Pistolas le entrega a Donald un catalejo para que pueda ver "lo bueno", a saber, unas atractivas bañistas. En dicho instante, el hasta entonces carácter pausado, rítmicamente estable y predominantemente melódico de la música incidental se ve interrumpido por el característico grito de Pancho Pistolas. No obstante, es el saludo que realizan las bañistas al trío de aves lo que provoca una desaforada reacción, lo que dialoga con un cambio radical en el carácter de la música y una velocidad en la acción, sobre todo en el momento en el que el sarape volador es utilizado tal cual avión de combate, superponiendo a la música incidental el sonido de este tipo de nave y sus municiones.

Luego del desarrollo de algunos juegos de las bañistas con Donald -entre ellos, persecuciones con los ojos vendados-, Pancho Pistolas decide, no sin el reclamo de Donald, cambiar de destino. De esta forma, esta suerte de guía turístico abre el libro con estampas de México que forma parte del regalo hecho a Donald. En otra página de este se muestra una representación animada y sonora de una noche en Ciudad de México. No obstante, 

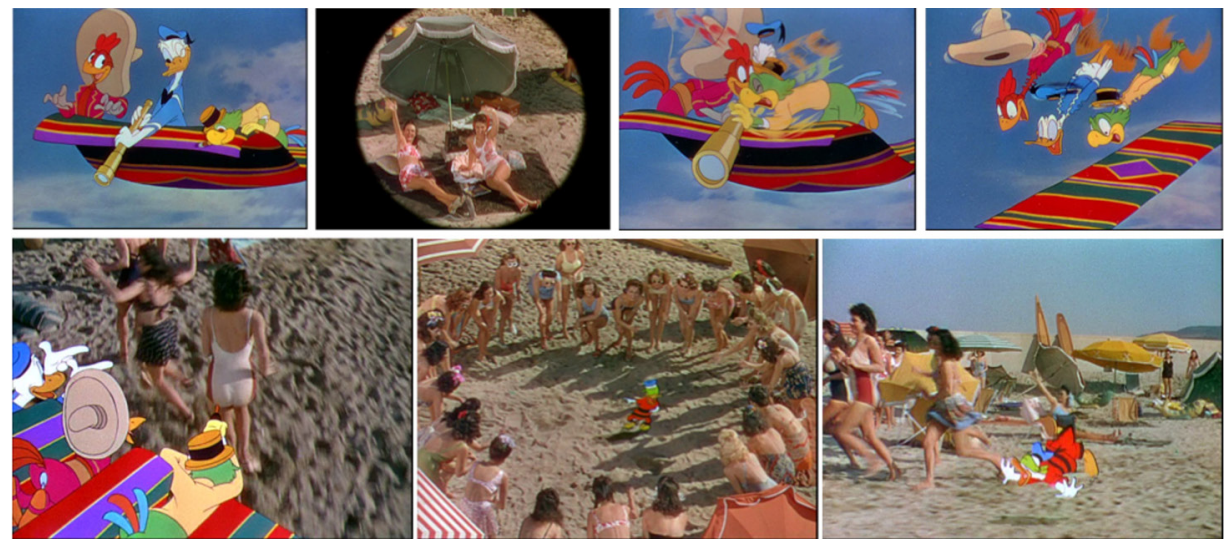

Figura 11: El trastorno de los tres caballeros con las bañistas de Acapulco.

la modernidad no es un tópico aquí desarrollado e inmediatamente el foco de la escena se posiciona en la animación de un cielo estrellado, desde el cual aparece el rostro de la cantante mexicana Dora Luz, causando, como es de suponerse, el abrupto entusiasmo de Donald. La canción que aquí interpreta esta cantante es el bolero "Solamente una vez", de Agustín Lara, adaptada al inglés también por Ray Gilbert como "You belong to my heart". Junto a la voz de Dora Luz, se escucha la orquesta del estudio, dirigida por Wolcott, donde destacan los violines y el uso de la clave. Finalizada la canción, varios labios animados se acercan a Donald y lo besan en diversas partes del rostro, provocando nuevamente una sobrerreacción en el aludido plumífero. Esta vez, eso sí, Donald se transporta a un mundo onírico y de carácter cada vez más sicodélico. En este nuevo escenario volará moviendo sus alas como un colibrí, buscando entre diversas flores alguna de la cual poder alimentarse. La música aquí es nuevamente el bolero de Lara, pero ya en ritmo de vals y en un pulso más rápido. De la flor elegida por Donald, aparecerá en la zona de sus pistilos el rostro de Dora Luz, cantando nuevamente la melodía de Lara, pero con un acompañamiento orquestal en el que se destaca una celesta y los violines desarrollando un material temático no solo en su ámbito más agudo, sino también en otra tonalidad, generando una musicalización tensa, llena de disonancias, emparentada a la idea de sicodelia si se toma en cuenta el contexto estrictamente tonal del filme [Ver resumen de secuencia en Clip $\mathrm{N}^{\circ} 11$ ].
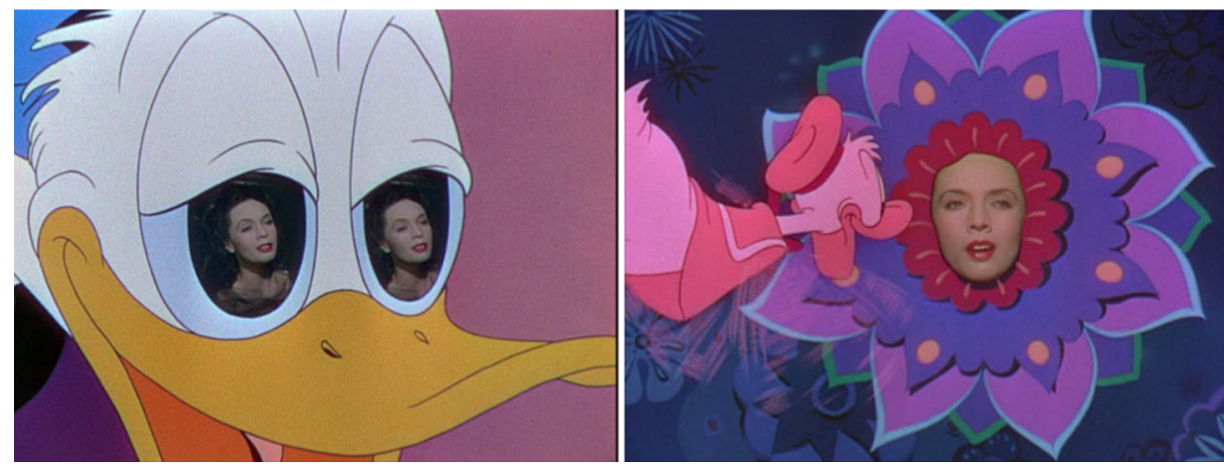

Figura 12: Donald embelesado esta vez con la cantante mexicana Dora Luz. 
Es en este momento en el que se hace patente otro elemento que marca una diferencia radical con Saludos Amigos. Me refiero aquí al "caos", usado como un recurso expresivo -con un correlato sonoro- que toma un gran impulso en esta sección final del filme.

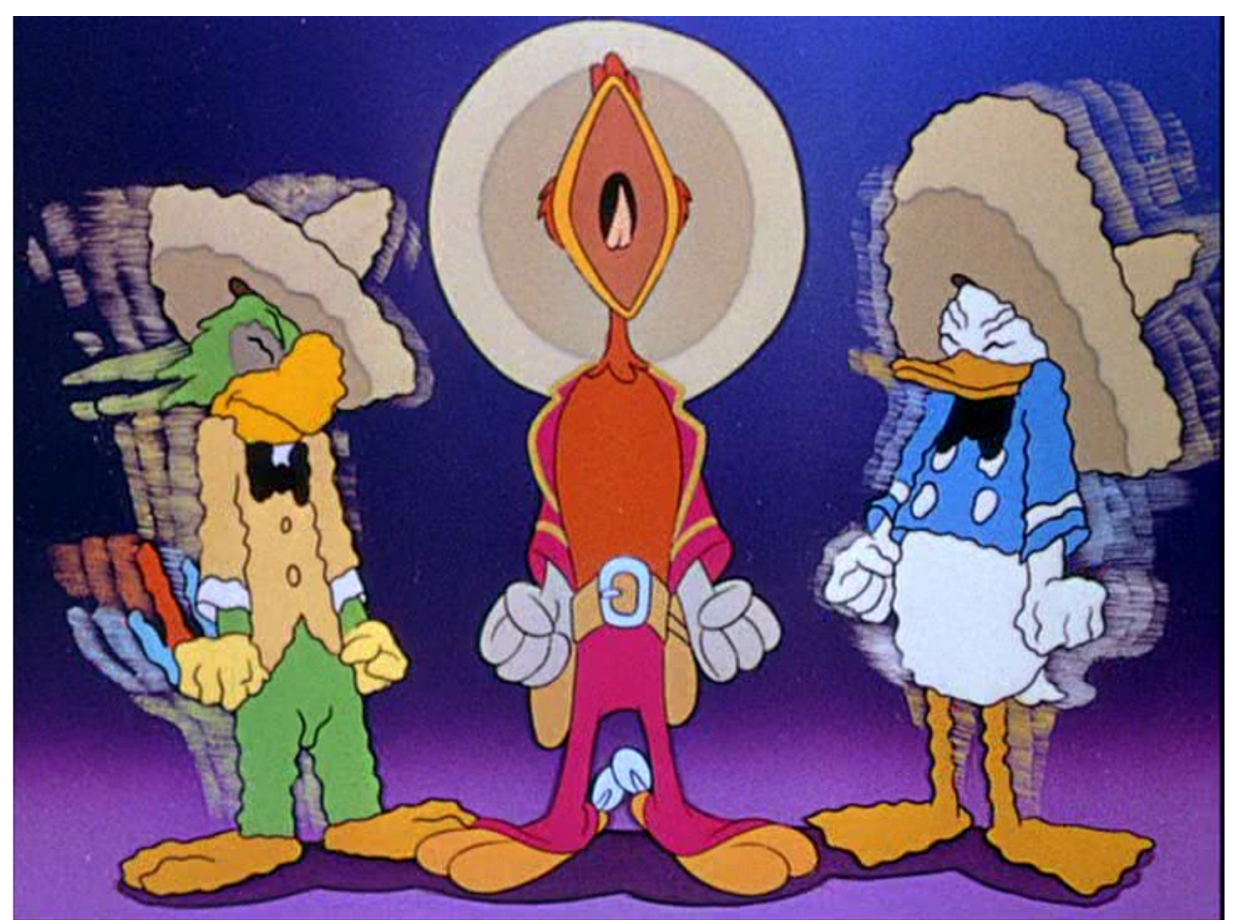

Figura 13: El nuevo personaje de The Three Caballeros, Pancho Pistolas, y su "marca sonora": un estridente grito que constituye una exageración de los gritos característicos de la música tradicional mexicana.

Para potenciar el ambiente de fantasía y el creciente caos, cada acercamiento de Donald a Dora Luz es intervenido por sorpresivas apariciones de Pancho Pistolas y José Carioca, potenciadas por una estridencia visual -basada en colores fuertes y mucho contraste- y una estridencia sonora que irrumpe con sonidos de balazos, la entonación repetida de la frase "We're three caballeros" en velocidad aumentada -provocando una sonoridad vocal estridente y aguda- y la intervención de unas entrecortadas frases en trompetas y maderas, sumando luego más balazos e intensos gritos de Pancho Pistolas. Esta lógica narrativa continúa, así como también las variaciones orquestales que se realizan con "You belong to my heart" hasta que Donald le da un beso a Dora Luz, momento en el que, embelesado, suena nuevamente un pasaje disonante en las cuerdas y celesta, y luego se ve rodeado de flores con rostros de atractivas mujeres, lo que es oníricamente sonorizado con una voz masculina que susurra cuatro veces "pretty girls" (ver Figura 14). 


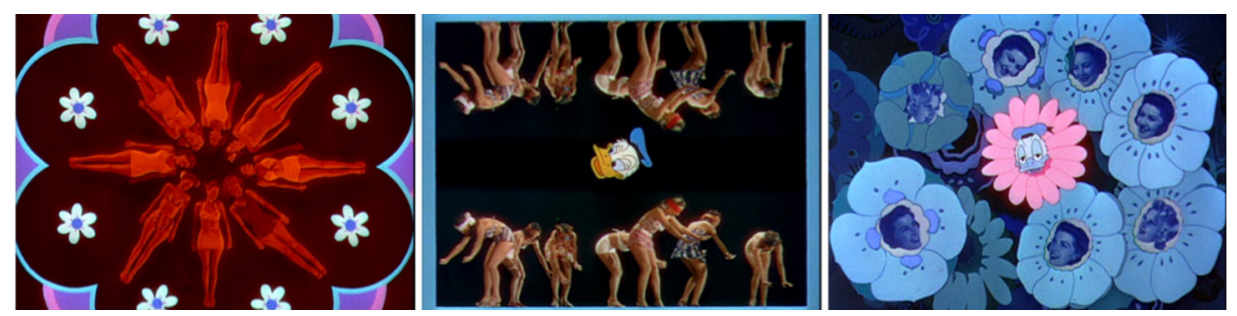

Figura 14: El paraíso onírico de Donald en The Three Caballeros, lleno de Pretty girls o Latin babies.

El estado de ensoñación de Donald adquiere un pulso regular y constante, así como una baja en la estridencia cuando empieza a sonar "La Sandunga", canción con una melodía de supuesto origen andaluz, que se asume arreglada por Andrés Gutiérrez, versión a la que Máximo Ramón Ortiz le añadió texto hacia mediados del siglo XIX. En el filme, "La Sandunga" es danzada por Carmen Molina (1920-1998), quien también llama la atención de Donald. Destaca aquí el contraste generado por esta intervención, de ritmo regular-vals-, cantada por voces femeninas e instrumentada por marimbas [Ver resumen de secuencia en Clip $\left.\mathrm{N}^{\mathrm{o}} 12\right]$.

Es significativo indicar que, con posterioridad a esta secuencia, se inicia la sección de cierre del filme, la que comienza con un baile de Carmen Molina y la animación de unos cactus danzantes, quienes, con Donald incluido, bailan una versión instrumental de la polka "Jesusita en Chihuahua", una de las canciones emblemáticas de la Revolución Mexicana escrita por Quirino Mendoza y Cortés hacia 1916. Luego, la intensidad se retoma, representándose una corrida de toros y golpes de piñata, elementos desde los que se produce un cierre abrupto y caótico del filme, negándose un cierre argumental más definido como ocurre en el lenguaje de Disney.

\section{REFLEXIONES AL CIERRE}

Este artículo se propuso abordar las maneras en que la música reforzó el lenguaje propagandístico contenido en Saludos Amigos y The Three Caballeros, esto con la finalidad de contribuir a una mayor integración de lo musical en las lecturas y debates académicos acerca de estos filmes. Fue a partir del análisis de dichas producciones -y, por supuesto, a partir también del trabajo de la literatura citada- que puedo sostener que la música fue probablemente el medio más persuasivo y estratégico utilizado por la industria fílmica hollywoodense para desarrollar representaciones de lo latinoamericano que tributaron al proyecto de hegemonía implícito en la Política del buen vecino. Para este fin, dicha industria, bajo la supervisión y apoyo del gobierno estadounidense, se propuso primeramente revertir ciertos estereotipos que reforzaban ideas poco favorables de América Latina que, paradójicamente, esta misma industria había ayudado a consolidar - promiscuidad, deshonestidad, sentimentalismo, flojera, salvajismo, entre otras-, esto mediante la producción de representaciones que realzaban más bien aspectos particulares de la región -su cultura, geografía, flora, fauna, entre otros- que podían resultar interesantes, atractivas e incluso educativas para las audiencias estadounidenses. Saludos Amigos es un claro ejemplo de esto. A su vez, junto con estos aspectos particulares acerca de América Latina, se ensalzaron también puntos en común entre dicha región y Estados Unidos, con la finalidad de consolidar un ideal de diálogo, cooperación y unión panamericana. 
En términos musicales, este tipo de producciones recurrió a procedimientos tales como la inclusión de músicos y agrupaciones latinoamericanas en pantalla, así como al uso de repertorio de diversas tradiciones musicales de las regiones latinoamericanas aludidas, donde también se lucieron instrumentos y conformaciones instrumentales específicas. Ahora bien, uno de los procedimientos que más llamó mi atención fue la recurrencia a generar secuencias con un diálogo, alternancia o fusión de tradiciones y estilos musicales latinoamericanos y estadounidenses con sus consecuentes danzas e idiomas, con el fin de simbolizar, desde una perspectiva musical, un diálogo e intercambio amistoso y supuestamente horizontal entre la cultura estadounidense y la latinoamericana.

En los procedimientos recién mencionados destacaron recursos tanto tímbricos como rítmicos. Los primeros fueron utilizados para ofrecer sonoridades distintas a las de los instrumentos musicales del canon sinfónico europeo o la música popular estadounidense, acudiendo, por ejemplo, a idiófonos de ascendencia aborigen afroamericana -como los utilizados en los pasajes que se interpretan sambas-, o a la instrumentación propia de diversas conformaciones y ensambles. En cuanto al ritmo, este fue pensado como un recurso con connotaciones primitivistas, directamente relacionado con lo corporal y, en consecuencia, lo sexual. Ambos recursos constituyeron, a mi juicio, un factor de novedad para las audiencias estadounidenses, contribuyendo a inscribir en la cultura de masas una idea de lo latinoamericano por lo general basada en lo festivo, tropical, sensual, intenso, salvaje y exuberante. Asimismo, creo que este fenómeno producido desde la industria fílmica resultó fundacional, tanto en términos de construcción como de inscripción y proyección, de una noción de lo que a partir de entonces se entiende en la industria musical global como "música latina". De este modo, asumo aquí un rol activo de la música en la construcción de alteridad, entregando un contenido sonoro al proyecto de hegemonía estadounidense.

Ahora bien, antes de cerrar este escrito quisiera mencionar que uno de los aspectos que más me llamó la atención durante la elaboración de este trabajo fue la indiferencia absoluta, por parte de la literatura académica revisada, hacia la infancia como un tópico a considerar dentro de sus análisis de los filmes aquí tratados. Esto a pesar de haber sido producidos por la más poderosa -y probablemente la más longeva- empresa fílmica dedicada a dicho segmento de la sociedad, la que durante este período, por medio de la producción de largometrajes animados como Snow White and the Seven Dwarfs (Cottrell et al. 1937), Pinocchio (Ferguson et al. 1940), Fantasia (Algar et al. 1940) y Dumbo (Armstrong et al. 1941), comenzó a definir lo que entendemos actualmente como cine infantil. Si bien la indiferencia evidenciada puede deberse a esta indefinición de un público cinematográfico infantil y un mercado que responde al mismo, no resulta menor pensar en una enorme cantidad de elementos presentes en estos filmes que no hubieran sido considerado aptos para un público infantil por la censura del establishment estadounidense. Y más allá del contenido propagandístico de Saludos Amigos -el que, como ya se mencionó, resultaba bastante solapado-, me refiero aquí a elementos narrativos de The Three Caballeros como la sicodelia -presente en Dumbo y otros cortometrajes de los estudios Disney, pero utilizada aquí con mayor intensidad y extensión-; simbología sexual y genital; un intenso bullicio; y, finalmente, personajes de Disney bebiendo alcohol, fumando, gritando, usando pistolas, coqueteando entre ellos -siendo del mismo sexo biológico- y acosando persistentemente a cuanta mujer se cruzaba en su camino. Si bien estos elementos narrativos no hubieran sido permitidos por los códigos éticos y morales de la sociedad blanca -expresados en la industria fílmica mediante una censura ya afianzada desde la década anterior-, sí lo fueron en el marco de un mundo de representaciones de Otros, en este caso lo latinoamericano, poniéndose una vez más en práctica un lenguaje representacional y exotizante que Hollywood ya tenía en sus códigos y procedimientos al trabajar con el afroamericano, el indígena o los imaginarios vinculados al medio y lejano oriente. 
Si bien este artículo no está centrado en la infancia, es esta la que me deja las principales motivaciones para continuar pensando en producciones como Saludos Amigos o The Three Caballeros: ¿Cómo aparece el infante en los filmes? ¿Habla por sí mismo? ¿Cómo se le habla? ¿Qué músicas y sonidos se utilizan al evocarlo? Y, sobre todo, ¿De qué maneras el lenguaje musical -y pienso aquí en el componente instrumental más que en las líricas, construcción más bien relacionada a la lógica adulta- nos puede acercar y brindar nuevas oportunidades de pensar la infancia?

\section{BIBLIOGRAFÍA}

Almeida, Lia, y Lílian Muneiro

2013 "Alô Amigos! Zé Carioca como representante nacional". Ponencia presentada en el XV Congresso de Ciências da Comunicação na Região Nordeste. 12 al 14 de junio, Recife, Brasil.

Bender, Pennee

2002 "Film as an Instrument of the Good Neighbor Policy, 1930s-1950s". Tesis de doctorado, New York University.

Berndt Morris, Elizabeth y Charles Morris

2011 "Walt Disney and Diplomacy: The Musical Impact of Aquarela do Brasil". Ponencia presentada en el Latin American Music Center's Fiftieth Anniversary Conference "Cultural Counterpoints: Examining the Musical Interactions between the U.S. and Latin America”, 19 al 23 de octubre, Bloomington, Estados Unidos.

Bodart, Oliver Nicolas Ronald François

2019 "A concepção norte-americana do Brazil perante a Política Externada da Boa Vizinhança: O caso Zé Carioca (1942-1945)". Ponencia presentada en el 6 Seminário Fluminense de Pós-Graduandos em História / $5^{\text {a }}$ Jornada do Programa de Pós-Graduação em História das Ciências e da Saúde "História \& Parcerias", 21 al 25 de octubre, Rio de Janeiro, Brasil.

Burton-Carvajal, Julianne

1994 “'Surprise Package’: Looking Southward with Disney”, Disney Discourse: Producing the Magic Kingdom. Eric Smoodin (editor). Nueva York y Londres: Routledge, pp. 131-147.

CARTwright, Lisa y Brian Goldfarb

1994 "Cultural Contagion: On Disney's Health Education Films for Latin America”, Disney Discourse: Producing the Magic Kingdom. Eric Smoodin (editor). Nueva York y Londres: Routledge, pp. 169-180.

Conyers, Claude

2012 "Foxtrot", Grove Music Online. Oxford Music Online. Oxford University Press. Recuperado de https://www.oxfordmusiconline.com/grovemusic/view/10.1093/ gmo/9781561592630.001.0001/omo-9781561592630-e-1002219055 [acceso: 29 de noviembre de 2020].

Dorfman, Ariel y Armand Mattelart

1973 Para leer al Pato Donald. Valparaíso: Ediciones Universitarias de Valparaíso.

GALM, ERIC A.

2008 "Baianas, Malandros, and Samba. Listening to Brazil through Donald Duck's Ears", Global Soundtracks. Worlds of Film Music. Marc Slobin (editor). Middletown: Wesleyan University Press, pp. 258-80

Goldman, Karen S.

2013 "Saludos Amigos and The Three Caballeros: The Representation of Latin America in Disney's Good Neighbor Films", Diversity in Disney Films: Critical Essays on Race, Ethnicity, Gender, Sexuality and Disability. Johnson Cheu (editor). Carolina del Norte: Mc Farland \& Company, pp. 23-37. 
González, Juan Pablo y Claudio Rolle

2004 Historia social de la música popular en Chile, 1890-1950, Santiago: Ediciones Universidad Católica de Chile.

Hess, CAROL

2017 "Walt Disney's Saludos Amigos: Hollywood and the Propaganda of Authenticity", The Tide Was Always High: The Music of Latin America in Los Angeles. Joseph Kun (editor). Oakland: University of California Press, pp. 105-23.

KaUfman, J. B.

2009 South of the Border with Disney. Walt Disney and the Good Neighbor Program, 1941-1948. New York: The Walt Disney Family Foundation.

Maccari Ferreira, Alexandre

2007 "A produção Disney em época de Segunda Guerra Mundial: cinema, história e propaganda". Ponencia presentada en el XXIV Simpósio Nacional de História "História e Multidisciplinaridade: territórios e descolocamentos”, 15 al 20 de julio, São Leopoldo, Brasil.

Massagli, Sérgio Roberto

2018 "A falsa representação da identidade brasileira na construção do personagem Zé Carioca da Disney”, Literartes, I/8, pp. 238-258. DOI: 10.11606/issn.2316-9826.literartes.2018.139877

Mendivil, Julio

2012 "Wondrous Stories: el descubrimiento de la pentafonía andina y la invención de la música incaica”, Resonancias, XVI/31, pp. 61-77.

Nelson, Andrew Kelly

2017 “José, Joe, Zé Carioca: Walt Disney’s Good Neighbor Colonial 'Monument' in Brazil”. Tesis de maestría, Brigham Young University.

Nuhfer-Halten, Bernice

2011 "Beyond the Ratoncito. Disney's idea of Latin America", Learning from Mickey, Donald and Walt. Essays on Disney's Edutainment Films. Anthony Bowdoin Van Riper (editor). Carolina del Norte: McFarland \& Company, pp. 209-220.

Pereira, Jéssica Reinaldo, y Renata Silveira Dutra

2015 "Saludações aos 'Bons Vizinhos': Alô Amigos, The three Caballeros e a relação entre Estados Unidos e América Latina”. Ponencia presentada en el Seminário América Latina "Cultura, História e Política,” 18 al 21 de mayo, Uberlândia, Brasil.

PiedRA, José

1994 "Pato Donald's Gender Ducking”, Disney Discourse: Producing the Magic Kingdom. Eric Smoodin (editor). Nueva York y Londres: Routledge, pp. 148-168.

Plitong, Ashley

2013 "Americanization as Global Politics: The United States Government's use of Disney as a Cultural Ambassador in Latin America During World War Two". Tesis de maestría, University of Ottawa.

Poveda, Juan Carlos

2019 "HELLO FRIENDS, CANTEMOS: La música en las representaciones de lo latinoamericano en largometrajes de ficción hollywoodenses durante el período de la Política del buen vecino (1933-1945)". Tesis de doctorado, Universidad de Chile.

Purcell, FERnANDo

2010 "Cine, propaganda y el mundo de Disney en Chile durante la Segunda Guerra Mundial", Historia, II/43, pp. 487-522.

RoSA, MARLI

2010 "Pato Donald no Batuque dos 'Bons Amigos': Manifestações culturais na Política da 'Boa Vizinhança'”. Ponencia presentada en el $9^{\circ}$ Encontro Internacional da Anphlac, 26 al 29 de julio, Goiás, Brasil. 
SHALE, RichaRD

1976 "Donald Duck Joins Up: the Walt Disney Studio During War World II". Tesis de doctorado, University of Michigan.

Telotte, Jay P.

2007 "Crossing Borders and Opening Boxes: Disney and Hybrid Animation", Quaterly Review of Film and Video, XXIV/2, pp. 107-16.

VAN Riper, ANTHONy Bowdoin (EDITOR)

2011 Learning from Mickey, Donald and Walt. Essays on Disney's Edutainment Films. Carolina del Norte: McFarland \& Company.

WATts, STEVEN

1997 The Magic Kingdom. Walt Disney and the American Way of Life. Columbia \& London: University of Missouri Press.

Filmografía citada

Algar, James, Samuel Armstrong, Ford Beebe Jr., Norman Ferguson, David Hand, Jim Handley, T. Hee, Wilfred Jackson, Hamilton Luske, Bill Roberts, Paul Satterfield, y Ben Sharpsteen. 1940. Fantasia. Walt Disney Productions.

Armstrong, Samuel, Norman Ferguson, Wilfred Jackson, Jack Kinney, Bill Roberts, Ben Sharpsteen, y John Elliotte. 1941. Dumbo. Walt Disney Productions.

Atkins, Thomas. 1935. Hi, Gaucho! Radio Keith Oprpheum.

Cottrell, William, David Hand, Wilfred Jackson, Larry Morey, Perce Pearce, y Ben Sharpsteen. 1937. Snow White and the Seven Dwarfs. Walt Disney Productions.

Ferguson, Norman, Clyde Geronimi, Jack Kinney, Bill Roberts, y Harold Young. 1944. The Three Caballeros. Walt Disney Productions.

Ferguson, Norman, T. Hee, Wilfred Jackson, Jack Kinney, Hamilton Luske, Bill Roberts, y Ben Sharpsteen. 1940. Pinocchio. Walt Disney Productions.

Ingram, Rex. 1921. The Four Horsemen of the Apocalypse. Metro Pictures Corporation.

Iwerks, Ub. 1928. The Gallopin' Gaucho. Walt Disney Productions.

Jackson, Wilfred, Jack Kinney, Hamilton Luske, y Bill Roberts. 1942. Saludos Amigos. Walt Disney Productions.

Jones, F. Richard. 1927. The Gaucho. Elton Corporation.

Thomas, Theodore. 2008. Walt E El Grupo. Theodore Thomas Productions. 